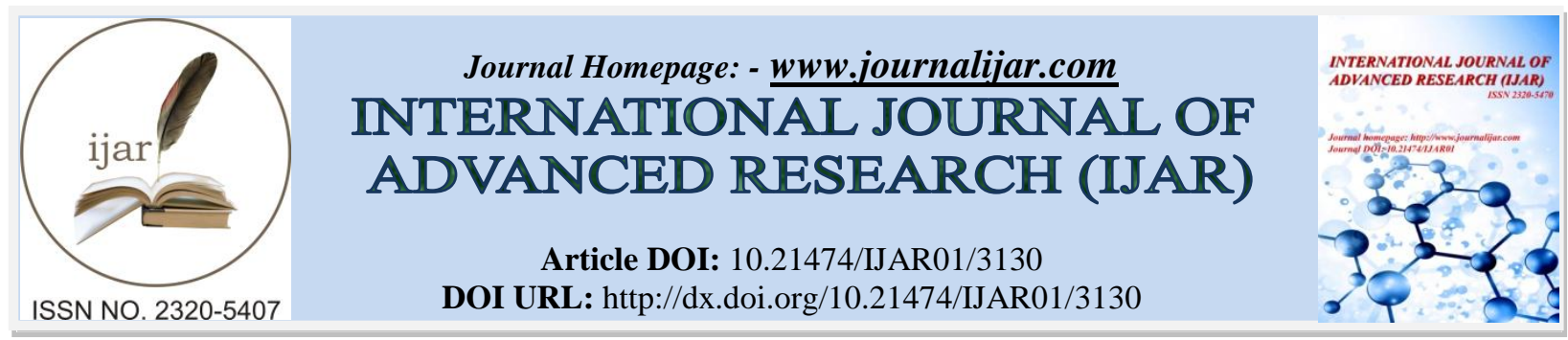

RESEARCH ARTICLE

\title{
HEPATOPROTECTIVE EFFECT OF NIGELLA SATIVA ON DIABETIC MICE.
}

Sneha Navin ${ }^{1}$, Jaykar Jha ${ }^{1}$, Abhinav ${ }^{1}$, Arun Kumar ${ }^{2}$, Mohammad Ali ${ }^{2}$, Ashok Ghosh ${ }^{2}$ and Ranjit Kumar ${ }^{2, *}$. 1. Department of Biotechnology, L. N. Mithila University, Darbhanga.

2. Research Centre, Mahavir Cancer Sansthan and Research Centre, Patna.

\section{Manuscript Info}

Manuscript History

Received: 13 December 2016

Final Accepted: 16 January 2017

Published: February 2017

Key words:-

Alloxan, Glucose, Liver, Nigella sativa,

\begin{abstract}
Diabetes mellitus is a major health problem for the people of the world. Diabetes is a chronic metabolic disorder resulting from a variable interaction of hereditary and environmental factors and it is characterized by abnormal insulin secretion or insulin receptor affecting $\beta$ cells of pancreas. Itis associated with a number of chronic complications including nephropathy, neuropathy, retinopathy and cardiovascular diseases. Diabetes mellitus affects a large number of people throughout the world and India also. Experts estimate that diabetic population will grow from 195 to 360 million by 2030 almost 4.5 percentage of the global population. Present study included histological and biochemical parameters of mice. Three groups of mice were prepared for comparative study on control, diabetic, and N. sativa .Diabetic models were prepared in mice by intraperitoneal administration of single dose of alloxan@120mg/kg b.w. Alcoholic extract of Nigella sativa was administered @ $100 \mathrm{mg} / \mathrm{kg}$ b.w/day for four and eight weeks. In diabetic group of mice glucose, creatinine, urea and SGPT were increased. Effective restoration was observed in glucose, SGPT, urea and createnine of $N$. sativa administered diabetic group of mice. Liver also shows effective restoration in $N$. sativa administered group of mice. Thus, it is concluded from study that alcoholic extract of N.sativa restores glucose level to normal. Nigella sativa acts effectively on diabetes mice on biochemical and histological parameters.
\end{abstract}

\section{Introduction:-}

Incidence of diabetes is increasing worldwide at an alarming rate. Diabetes is on a rapid rise in developing nations ${ }^{1}$. People suffering with diabetes is projected to rise from 171 million in 2000 to 366 million in $2030^{2}$. The past two decades have seen an explosive increase in the number of people diagnosed with diabetes worldwide ${ }^{3}$. The World Health Organization has predicted that the diabetic patients will occur in the developing countries and increase $42 \%$ in the developed countries and $170 \%$ increase in the developing countries. The countries with the largest number of diabetes patients are India, China and United States ${ }^{4}$.

India has the largest number of people with diabetes in the world. Diabetes is a group of common metabolic disorders that share the phenotype of hyperglycemia ${ }^{5}$. Diabetic hyperglycaemia indicate that plasma levels of urea 
and creatinine which are considered as perfect markers of renal dysfunction ${ }^{6}$.Adults with DM have cardiovascular disease death rates that are 2-3 times higher than adults without $\mathrm{DM}^{7}$.

Medicinal plants used in India has been practiced for more than 5,000 years. Medicinal plants used for prevention of disease, rejuvenation of our body systems, and extension of life span through lifestyle and natural therapies ${ }^{8}$. According to the WHO, over $80 \%$ of the world's population relies on traditional forms of medicine, largely plant based to meet primary health care needs.

Nigella sativa has been used for medicinal purposes for centuries $N$. sativa traditionally used for a variety of conditions and treatments related to respiratory health, stomach and intestinal health, kidney and liver function, circulatory and immune system ${ }^{9}$.Nigella sativa possess biological, pharmacological and biochemical actions, including antibacterial bronchodilator and anti-parasitic ${ }^{10}$.Nigella sativa oil has the ability to protect testis against oxidative stress possibly through antioxidant effects of its bioactive compounds ${ }^{11}$.After the treatment of Nigella which decreases the elevated lipid peroxidation, liver enzyme levels and increases the reduced antioxidant enzyme levels ${ }^{12}$.Nigella oils has gastro protective activity against gastric mucosal injury ${ }^{13}$.

Present study is designed to evaluate effect of Nigella sativa on histological and biochemical parameters of liver in diabetic mice.

\section{Materials and Methods:-}

Animals: - The mice (Mus musculus) were reared in animal house. The mice were selected for the study was 12 weeks old with $30 \pm 2$ gm body weight (b.w). The mice were housed at controlled environmental conditions $22 \pm 2^{\circ} \mathrm{C}$, relative humidity $50 \pm 10 \%$, and $12 \mathrm{~h}$ dark-light cycle. All experimental were conducted as per the guidelines of CPCSEA (Committee forthe Purpose of Control and Supervision of Experiments on Animals).

Chemicals: - Alloxan, purchased by Loba chem Pvt. Ltd., Mumbai was utilized for the experimental design.

Medicinal plant used: - Alcoholic seed extract of Nigella sativa is orally administered to diabetic group of mice.Fresh seed of Nigella sativawas purchased from herbal store in Patna, India.

Study groups \& sampling:- The control group of six mice received distilled water orally. The 'treatment' groups $(\mathrm{n}=6)$ received alloxan $120 \mathrm{mg} / \mathrm{kg}$ b.w by intra-peritoneal method for diabetic model preparation. Nigella sativa $(100 \mathrm{mg} / \mathrm{kg} / \mathrm{b} . w /$ day $)$ administered to diabetic mice orally through Gavage method. Mice were sacrificed after the scheduled treatment. Serum was collected for SGPT, glucose, creatinine and urea estimation. The Liver from all the mice were removed and washed three times in isotonic saline $(0.85 \mathrm{v} / \mathrm{w} \%)$ and fixed in neutral formalin for Light Microscope (LM) study.

\section{Results:-}

Fasting level of glucose was observed in every group of mice. Level of glucose in control group was $99.00 \pm 2.30$ $\mathrm{mg} / \mathrm{dl}$. In diabetic group it was $201.3 \pm 12.55 \mathrm{mg} / \mathrm{dl}$. While it was $135.0 \pm 3.46 \mathrm{mg} / \mathrm{dl}$ and $106.3 \pm 2.18 \mathrm{mg} / \mathrm{dl}$ in Nigella sativa 4 weeks and 8 weeks administered group of mice (Graph: I).

Serum Glutamate-Pyruvate Transaminase (S.G.P.T) level in control group of animal was $22.00 \pm 3.21 \mathrm{U} / \mathrm{ml}$. Diabetic group of mice S.G.P.T level was $312.3 \pm 4.09 \mathrm{U} / \mathrm{ml}$. While itwas $255.0 \pm 3.78$ and $192.3 \pm 7.44 \mathrm{U} / \mathrm{ml}$ in Nigella sativa four weeks and eight weeks administered group of mice (Graph: II).

Level of Creatinine in control group of mice was $0.74 \pm 0.06 \mathrm{mg} \%$. In groupof diabeticmice creatinine level was $1.97 \pm 0.04 \mathrm{mg} \%$. Creatinine level was $1.71 \pm 0.01$ and $1.42 \pm 0.02 \mathrm{mg} \%$ in Nigella sativa four weeks and eight weeks administered group of mice (Graph: III).

Urea value in control group of mice was $20.33 \pm 2.33 \mathrm{mg} / \mathrm{dl}$. While in diabetic group of mice was $46.73 \pm 0.079$ $\mathrm{mg} / \mathrm{dl}$. Urea level was $39.37 \pm 0.33$ and $32.40 \pm 1.29 \mathrm{mg} / \mathrm{dl}$ in Nigella sativafour weeks and eight weeks administered group of mice (Graph: IV). 
In control group of mice, well-organized hepatic cells were observed. Distinct cytoplasmic and nuclear material was also observed. Central vein was well organized with its intact cell wall (Figure: 1). Liver of diabetic mice shows vacuolization. Clustered and multilobed nuclei were observed. Degenerated cytoplasmic materials were observed. Clustered nuclei were also shows on periphery on central vein (Figure: 2). Diabetic mice followed by four weeks of Nigella sativa administration shows vacuolization in hepatic cells. Clustered nuclei were shows in hepatic cells. Many vacuolated spaces were observed with degenerated central vein (Figure:3). Diabetic mice followed by 8 weeks of Nigella sativa administration shows restoration in nuclear material were observed to least extend. Restored cytoplasm was observed in liver cells. Least vacuolization were also observed (Figure: 4).

\section{Graph - I: Glucose level in serum of mice}

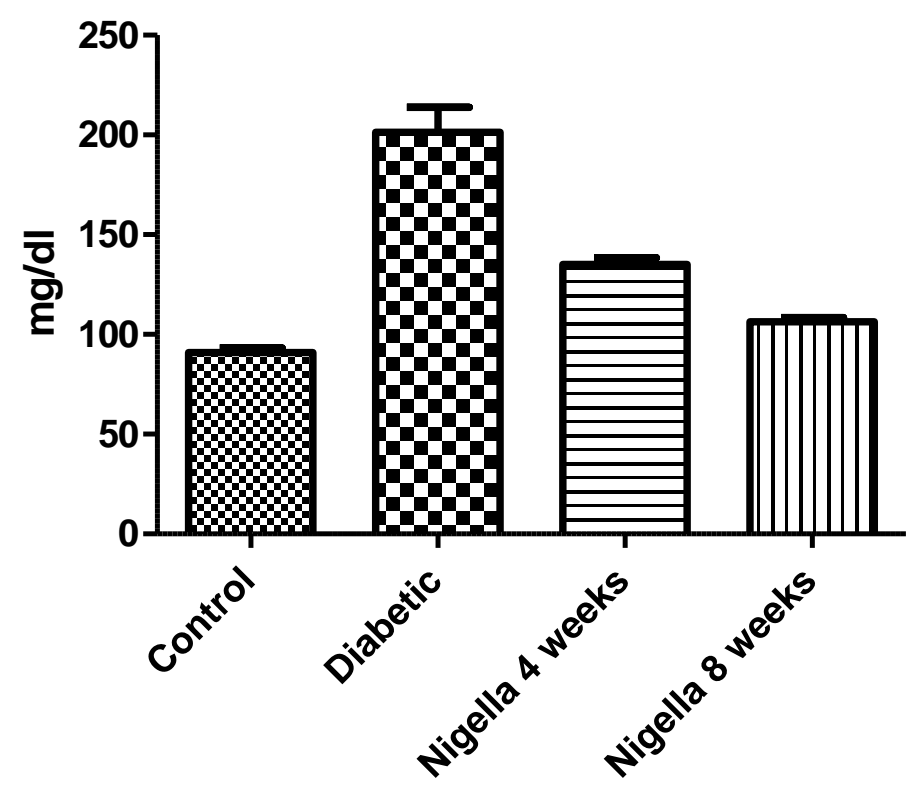

\section{Graph - II: SGPT level in serum of mice}

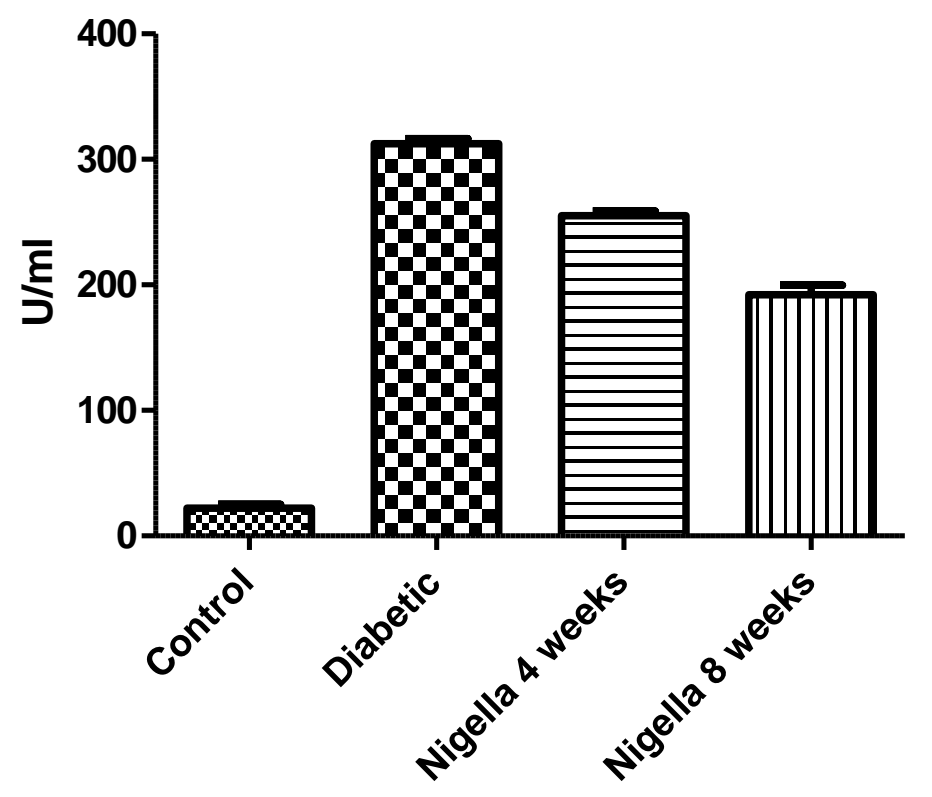


Graph - III: Creatinine level in serum of mice

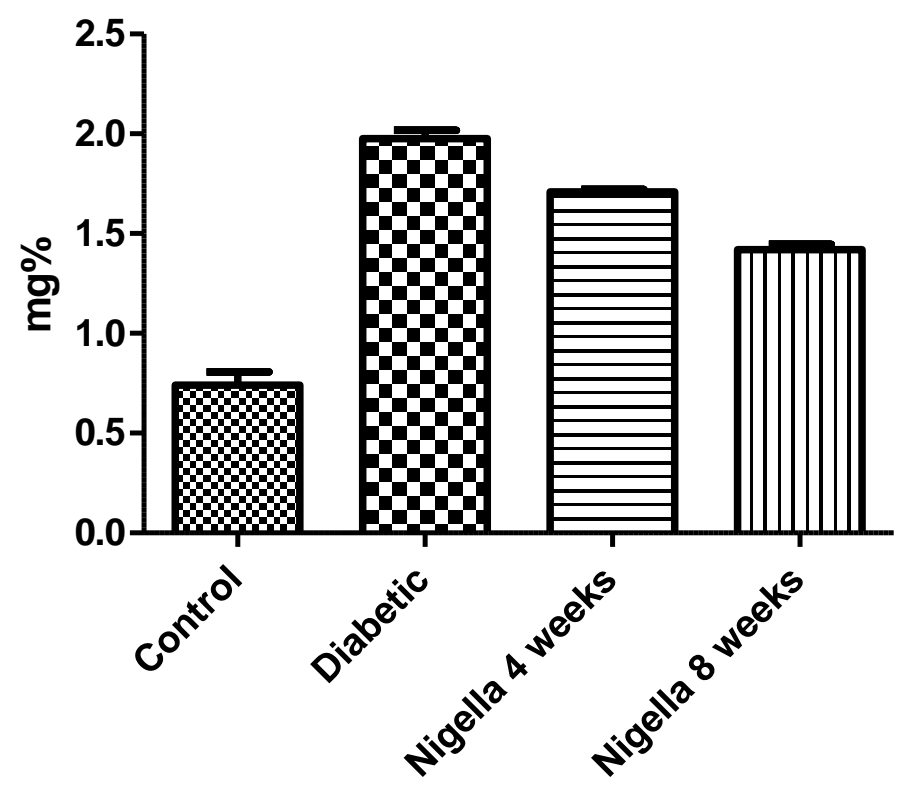

Graph - IV: Urea level in serum of mice

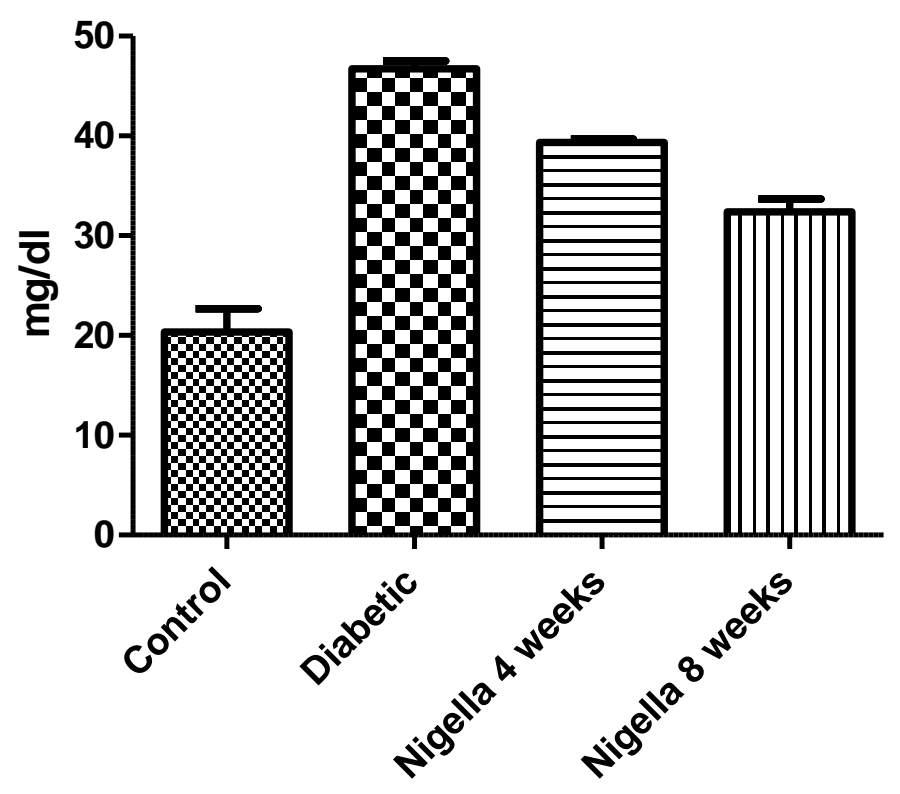




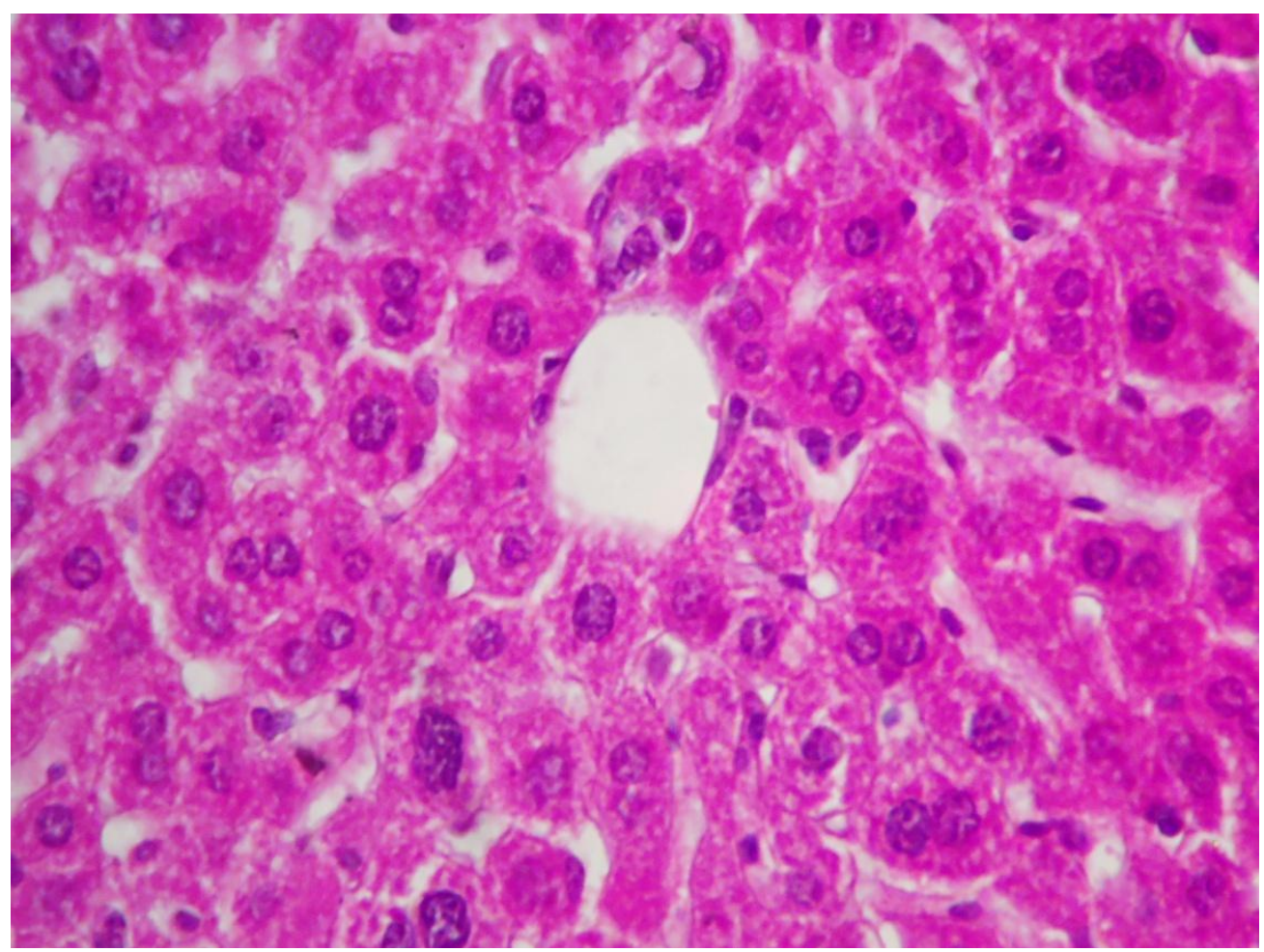

Figure 1:- In control group of mice well organized hepatic cells were observed. Distinct cytoplasmic and nuclear material was also observed. Central vein was well organized with its intact cell wall. X 600.

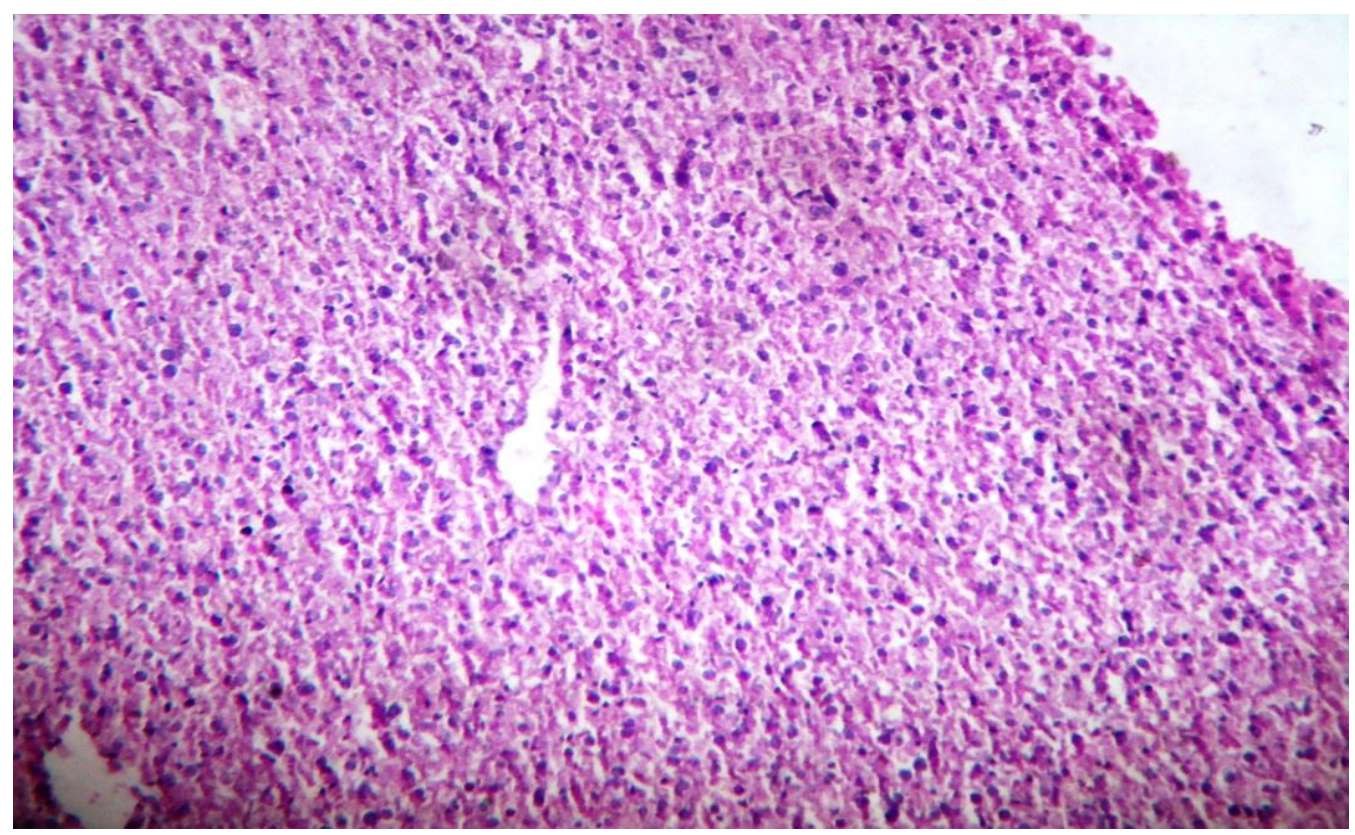

Figure 2:- Liver of diabetic mice shows frequent vacuolization. Clustered and multilobed nuclei were observed. Degenerated cytoplasmic materials and Clustered nuclei were also observed on periphery on central vein. X 200. 


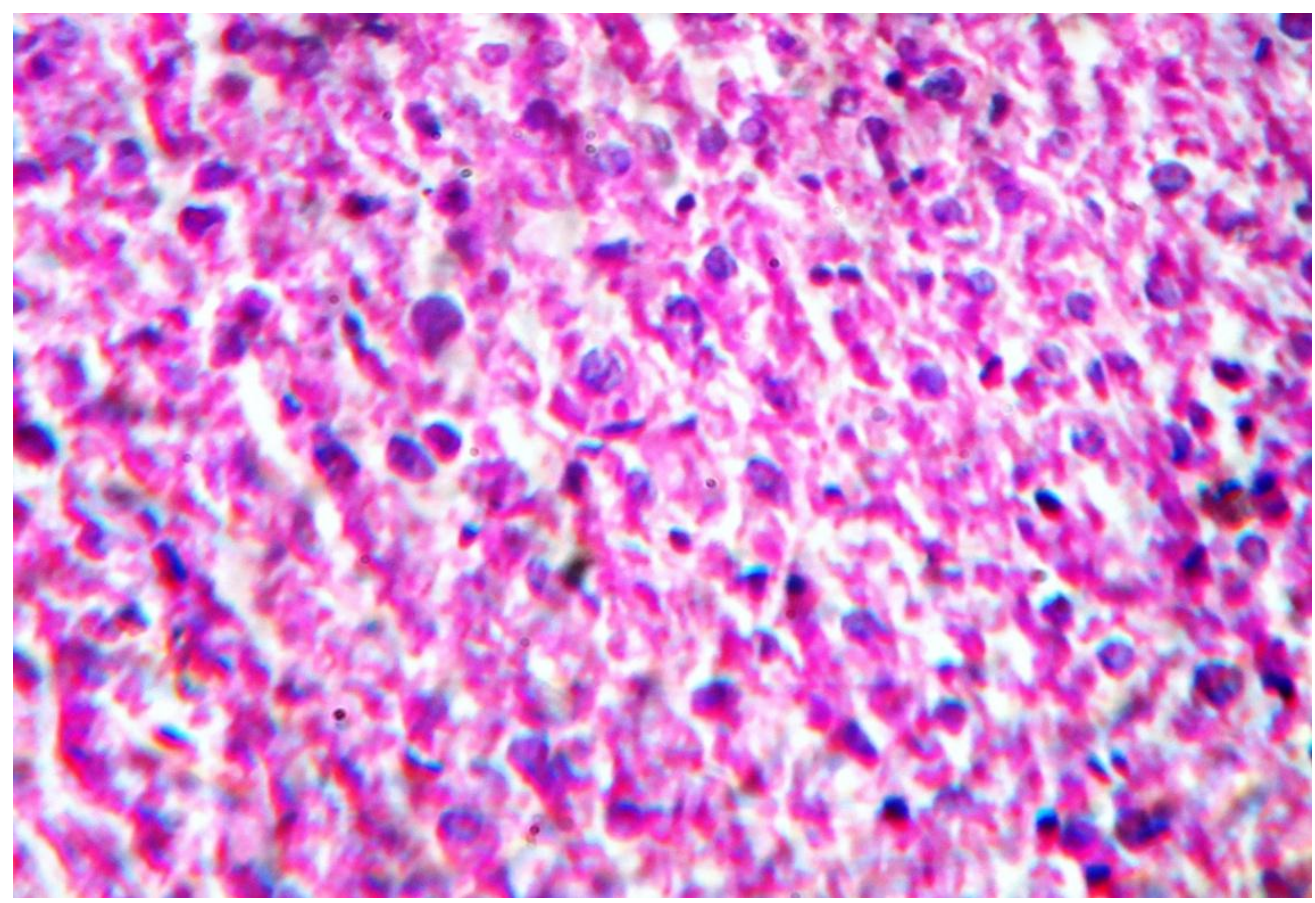

Figure: 3:- -Liver of diabetic mice followed by four weeks shows degenerated hepatic cell. Many vacuolated spaces were observed degenerated cytoplasm. Fragmented nuclear materials were observed. Vacuolization were also observed nuclear material of liver cells. X 600.

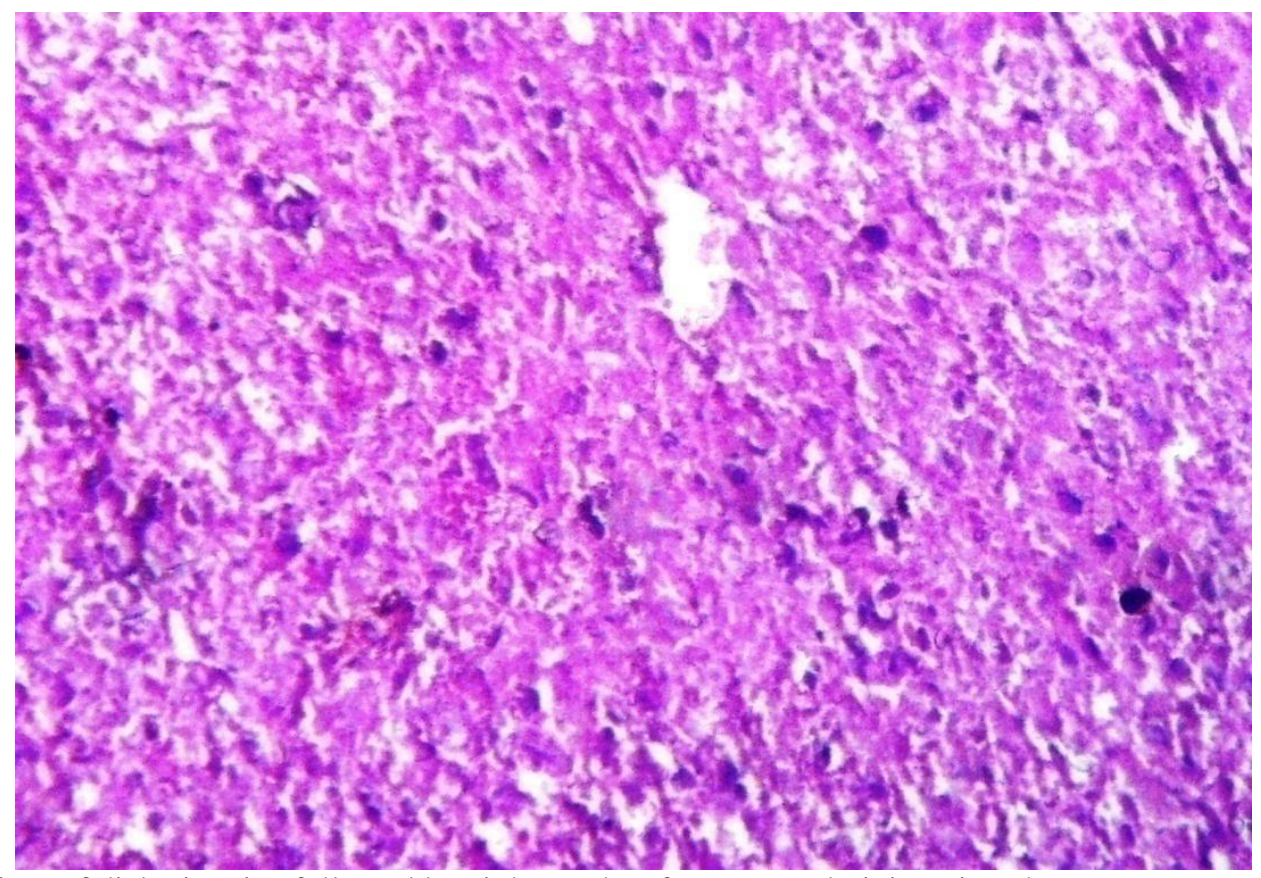

Figure 4:- Liver of diabetic mice followed by eight weeks of N.sativa administration shows many vacuolated spaces with degenerated nuclei of hepatic cells. Multilobed and vacuolated nuclear materials were observed. Central vein was also observed in degenerated condition. X 200. 


\section{Discussions:-}

Diabetic hyperglycemias induce certain biochemical parameter such as increased blood urea production in diabetes by enhancing catabolism of liver \& plasma protein. Recent scientific investigations have also confirmed the efficacy of plant preparations, few of which are most effective against diabetes ${ }^{14}$.In diabetes, Oxidative stress was thought to be a result of free radicals generated during autoxidation of glucose ${ }^{15}$. In diabetes blood urea level increases \& reason behind this is due to increased catabolism of both liver \& plasma proteins. This elevation of plasma level of urea $\&$ creatinine is marker of renal dysfunction ${ }^{16}$. In our study we have observed in urea and creatinine level about threefold increases in diabetic group of mice.

Another study based on carbon tetrachloride induced rats has shown that $\mathrm{CCl} 4$ treatment increased the lipid peroxidation and liver enzymes, and decreased the antioxidant enzyme levels and furthermore, Nigella sativa treatment decreased the elevated lipid peroxidation, liver enzyme levels and increased the reduced antioxidant enzyme levels ${ }^{17}$. In present study S.G.P.T increases 13 folds in diabetic group of mice. Hepatic cellswere observed in degenerated condition with elongated and fragmented nuclear material. Many vacuolated spaces were also observed in cytoplasm of hepatic cells in diabetic group of mice.

NS alcoholic extract maintained the levels of AST, ALT and ALP close to normal against D -Galactosamine induced toxicity ${ }^{18}$. In present study Nigellasativacauses effective restoration in urea and creatinine level. S.G.P.T. level was restored effectively in $N$. sativa administered group of mice.

Nigella sativa causes effective restoration in malathion induced increases in AST, ALT, and lipid peroxidation. Nigella sativa also improvement role in liver function tests, lipid peroxidation, and antioxidant enzymes alteration induced by malathion ${ }^{19}$. Nigella sativaadministered group of mice shows effective restoration in SGPT level up to normal.NS showed hepatoprotective effects against isoniazid induced hepatotoxicity in rabbits and there are no histopathological or biological abnormalities were observed ${ }^{20}$. Nigella sativais efficient cytoprotectiveagainst CCl4induced hepotoxicity, possibly via inhibition of the production of oxygen free radicals that cause lipid peroxidation $^{21}$. In present study Nigellasativa causes restoration in hepatic cells. Central veins and sinusoids were also restored effectively. Restoration is observed in both cytoplasmic and nuclear material.

\section{Conclusions:-}

It is concluded from study that N.sativa acts effectively on SGPT level. Urea, uric acid and creatinine level were almost normal after $N$. sativa administration. It maintains normal morphology of hepatic cells with least vacuolization. Nigella sativa is effective cytoprotective agent on hepatocyte of diabetic mice as well as maintains biochemical parameters to normal level. It is evident from study that Nigella sativa acts well against diabetes.

\section{Acknowledgement:-}

The authors are thankful to Mahavir Cancer Institute and Research Centre for providing infrastructural facility during this work. We are also thankful to our entire research team who provided us every support during this study.

\section{References:-}

1. World Health Organization: Global Health Risks, Mortality and Burden of Disease Attributable to Selected Major Risks. December: 2010.

2. Wild S., Roglic G., Green A., Sicree R. and King H; Global prevalence of diabetes: estimates for the year 2000 and projections for 2030. Diabetes Care:2004; 27(5): 1047-53.

3. King H., Auburt RE. and Herman WH; Diabetes Care: 1998; 21:1414- 31.

4. Ramachandran A., Socioeconomic burden of diabetes in India. Suppl. JAPI: 2007; 55:9.

5. Kota S.K., Meher L.K., JammulaS, Kota S.K. and Modi K.D; Genetics of type 2 diabetes mellitus and other specific types of diabetes; its role in treatment modalities. DiabetesMetab. Syndr: 2012; 6, 54-58.

6. S. Silva, Y.T.C., Peres L.C. and Foss M.C; Enamel hypoplasia in a litter of rats with alloxan- induced diabetes mellitus. Braz. Dent. J: 2003;14(2):65-69.

7. Astrup AS., Cardiovascular morbidity and mortality in diabetes mellitus prediction and prognosis. Dan Med Bull: 2011; 58(8):B4152.

8. Garodia P., Ichikawa H.,Malani N., Sethi G. and Aggarwal BB;from ancient medicineto modern medicine: ayurvedic concepts of health and their role in inflammation and cancer. J SocIntegrOncol: 2007;5:25-37. 
9. Elshiekh Y.H.AndMona A M abdelmageed; Phytochemical screening and antimicrobial activity of Strigahermonthica and Nigella sativa seeds. American Journal of Research Communication: 2015; 3(3): 24-33.

10. El Tahir KE.,AshourMM.andal-Harbi MM; The cardiovascular actions of the volatile oil of the black seed (Nigella sativa) in rats: elucidation of the mechanism of action. Gen Pharmacol: 1993; 24(5):1123-31.

11. Danladi., J., S.A. Ahmed., S.P. Akpulu., G.K. Owolagba. and M.U. Iduh; Protective effect of cool extraction of black seed (Nigella sativa) oil against CCl4-induced oxidative damages in Wistar Rats testis. IOSR J. Pharmacy Biological Sci: 2013; 5: 68-74.

12. Kanter M., Coskun O. and Budancamanak M; Hepatoprotective effects of Nigella sativaL. and UrticadioicaL. on lipid peroxidation, antioxidant enzyme systems and liver enzymes in carbon tetrachloride-treated rats. W. J. Gastroenterol: 2005A; 11: 6684-6688.

13. Zaidi SF., Yamada K., Kadowaki M., UsmanghaniK.and Sugiyama T; Bactericidal activity of medicinal plants, employed for the treatment of gastrointestinal ailments, against Helicobacter pylori. J Ethnopharmacol: 2009;121: 286-91.

14. Krishnamurthy, B., J. Chee, G. Jhala, S. Fynch and K.L. Graham et al., 2012. Complete diabetes protection despite delayed thymic tolerance in NOD8.3 TCR transgenic mice due to antigen-induced extrathymic deletion of T Cells. Diabetes, 61: 425-435.

15. Armas LA, Akhter MP, Drincic A and Recker RR. Trabecular bone histomorphometry in humans with Type 1 Diabetes Mellitus. Bone 2012; 50: 91-96.

16. Levey AS, Bosch JP, Lewis JB, Greene T, Rogers N, Roth D. A more accurate method to estimate glomerular filtration rate from serum creatinine: a new prediction equation. Modification of Diet in Renal Disease Study Group. Ann Intern Med 1999; 130: 461-470

17. Kanter M., Coskun O. and Budancamanak M; Hepatoprotective effects of Nigella sativaL. and UrticadioicaL. on lipid peroxidation, antioxidant enzyme systems and liver enzymes in carbon tetrachloride-treated rats. W. J. Gastroenterol: 2005A; 11: 6684-6688.

18. Gani MS, John SA. Evaluation of hepatoprotective effect of Nigella Sativa L. Int J Pharm PharmSci 2013;5:428-30.

19. El-Gharieb MA, El-Masry TA, Emara AM, HashemMA. Potential hepatoprotective effects of vitamin E and Nigella sativa oil on hepatotoxicity induced by chronic exposure to malathion in human and male albino rats. Toxicol Environ Chem 2010;92:391-40.

20. Hassan AS, Ahmed JH, Al-Haroon SS. A study of the effect of Nigella sativa (Black seeds) in isoniazid (INH)induced hepatotoxicity in rabbits. Indian J Pharmacol 2012;44:678-82.

21. Mansour MA. Protective effects of thymoquinone and desferrioxamine against hepatotoxicity of carbon tetrachloride in mice. Life Sci 2000;66(26):2583-91. 